\title{
CHIEF JUDGE DAVID L. BAZELON AS TEACHER: OBSERVATIONS BY A SOMETIME COLLABORATOR
}

\author{
ANDREW S. WATSON†
}

One of the social roles of a court is to participate in teaching the community what its law is. As judges write opinions, they construe statutes and prior decisions and these views then become part of the teaching materials for the next cycle of learning. In addition, and to varying degrees, judges participate in extra-judicial teaching. This kind of activity is more controversial, and many argue that it is inappropriate and prejudicial to a judge's courtroom function. ${ }^{1}$ Whatever value judgment one makes on this point, all would have to agree that Judge David $\mathrm{L}$. Bazelon, Chief Judge of the Court of Appeals for the District of Columbia Circuit, has been very active in extra-judicial teaching. Some of this activity is directed toward the legal profession, and some toward the "helping professions" of psychiatry, psychology, and social work. I have had the opportunity to participate and to observe at close hand some of Judge Bazelon's teaching activities with the latter group, and in this Article I will focus mainly upon that area of his work and make a psychiatrist's observations about it.

We do not yet have an assembled volume of Judge Bazelon's writings, but his publications are sufficiently extensive to qualify him to join Coke, Blackstone, Holmes, Cardozo, and Jerome Frank as promulgators of explicit jurisprudential views about a multitude of legal questions. Inspection of Judge Bazelon's published extra-judicial works gives ample evidence of the wide

† Professor of Psychiatry and Professor of Law, University of Michigan. B.S. 1942, University of Michigan; M.D. 1950, MM.S 1954, Temple University.

1 The inquiries regarding what constitutes a proper judicial function are well known. See, e.g., B. CARdozo, The Growth of THE LAll 62-80 (1924); Frankfurter, Some Reflections on Reading Statutes, 47 Colum. L. Rev. 527 (1947). For an analysis of the conscious-logical as well as some of the unconscious factors which affect the way courts approach their activism, see K. Llewelly. The Commonlaw Tradirion: Deciding Appeals 77-91 (1960). 
range of his jurisprudential explorations. ${ }^{2}$ I am particularly happy to contribute to this issue because I had the pleasure and stimulation of participating with Judge Bazelon as co-teacher early in his career as educator.

\section{Some Teaching Experiences}

My own experience in legal education began in 1955, shortly after Judge Bazelon's famous opinion in Durham v. United States. ${ }^{3}$ As I was groping to understand the ways in which psychiatrists and lawyers related to each other professionally, I encountered Douglas $v$. United States. ${ }^{4}$ I had already come to the conclusion that much of the intellectual commerce between these two professions could only be characterized as uncommunicative, mainly because neither group seemed to grasp the major concepts and concerns of the other. Douglas struck me instantly as an exciting exception to the kind of discussion I had come to expect. I had occasion to write Judge Bazelon and, having learned of the availability of "slip opinions," I requested a copy of Douglas. In doing so, I commented on the unusual quality of the opinion from the standpoint of its understanding of psychiatric issues. By return mail I received a copy of the opinion and a nice note from Judge Bazelon suggesting that sometime if I were in Washington, we should get together. Before opportunity took me to Washington, I received a phone call one Saturday afternoon from the judge, stating that he was visiting a friend in Philadelphia and inviting me to join him for a drink, which I did. We had an interesting and productive conversation discussing areas of mutual interest, and that was the beginning of my friendship with Judge Bazelon.

${ }^{2}$ See, e.g., Bazelon, Follow the Yellow Brick Road, 40 Am. J. ORTHOPsYchiat. 562 (1970); Bazelon, Implementing the Right to Treatment, 36 U. CHI. L. REv. 742 (1969); Bazelon, Justice Stumbles on Science, 1 IrISH JURIST 273 (n.s. 1966); Bazelon, Law, Morality, and Civil Liberties, 12 U.C.L.A.L. REv. 13 (1964); Bazelon, Mental Retardation: Some Legal and Moral Considerations, 35 Aм. J. ORThopsychiat. 838 (1965); Bazelon, Nezu Gods for Old: "Efficient" Courts in A Democratic Society, 46 N.Y.U.L. Rev. 653 (1971); Bazelon, Racism, Classism, and the Juvenile Process, 53 Judicature 373 (1970); Bazelon, The Concept of Responsibility, 53 GEo. L.J. 5 (1964); Bazelon, The Defective Assistance of Counsel, 42 U. CIN. L. REv. 1 (1973); Bazelon, The Interface of Law and the Behavioral Sciences, 271 New ENG. J. Med. 1141 (1966); Bazelon, The Law and the Mentally Ill, 125 Am. J. Psychiat. 665 (1968); Bazelon, "The Problem Child"-Whose Problem?, 13 J. Child Psychiat. 193 (1974); Bazelon, The Right to Treatment: The Court's Role, 20 Hosp. \& Community Psychiat. 129 (1969).

3214 F.2d 862 (D.C. Cir. 1954).

4239 F.2d 52 (D.C. Cir. 1956). 
I had just completed my second year of teaching at the University of Pennsylvania Law School and was becoming intrigued with the problems of a lawyer's education, especially as it relates to the psychology of the professional self image. ${ }^{5}$ One of the things I surmised from that meeting with Judge Bazelon was that he shared this interest, though he had had no formal experience as a teacher. It happened that at that particular time we needed a lawyer teaching collaborator for my seminars in the law school. My original co-teacher had departed and there was no great eagerness among my professorial colleagues to join in that venture. Following my discussion with Judge Bazelon, I suggested to the faculty that possibly he might be available to teach the seminar with me in the fall term. This met with their approval, and we contacted him. He accepted, and for one semester in each of the following two years he came weekly to Philadelphia to co-teach a seminar in Law and Psychiatry. Though I have referred to this seminar elsewhere, ${ }^{6}$ it warrants a brief summary here.

The materials that we used in that seminar were the early draft versions of what was ultimately to become Psychiatry for Lawyers. ${ }^{7}$ We had been experimenting with ways and means to utilize psychiatric concepts in the legal context, because it seemed clear that there had been little appropriate utilization of psychiatric information in law theretofore. Judge Bazelon shared my. eagerness to help students develop this skill. We were convinced that no amount of theoretical exploration or discussion, by itself, would enable students to utilize psychiatric data skillfully and appropriately. For this reason, by the second year's seminar offering we had evolved an interesting alternative technique. Judge Bazelon obtained a number of trial transcripts of cases which came before his court dealing with various psychiatric questions. Most of them related to problems around the defense of insanity. Instead of having students write a term paper, four students were assigned to one of those cases, one pair to serve as counsel for appellant and one pair as counsel for appellee. Each team would then write a brief and prepare to argue it. At the end of the semester we scheduled a two-day visit to Washing-

${ }^{3}$ See generally, Stone, Legal Education on the Couch, 85 Harv. L. Rev. 392 (1971); Watson, The Quest for Professional Competence: Psychological Aspects of Legal Education, 37 U. Cin. L. Rev. 91 (1968).

${ }^{6}$ See Watson, Reflections on the Teaching of Criminal Law, 37 U. DET. L.J. 701, 715 (1960).

${ }^{7}$ A. Watson, Psychiatry for Lawyers (1968). 
ton where moot court arguments on these cases would be heard in the Court of Appeals Courtroom, before a bench which included Judge Bazelon, Judge Washington, Mr. Abe Fortas, the then Solicitor General Simon Sobeloff, and myself. Coupled with this advocacy experience in arguing mental health issues, we had an afternoon seminar on juvenile delinquency at the National Institute of Mental Health, taught by the internationally famous expert, Dr. Fritz Redl. ${ }^{8}$ On the morning of the second day, we visited the John Howard Pavilion at St. Elizabeths Hospital, where students had the opportunity to interview several of the defendants in the D.C. Circuit cases including Wells, Leach, and Carter, ${ }^{9}$ as well as some of the doctors who had served as psychiatric expert witnesses. This permitted them to verify explicitly the impressions they gained from the trial records about the status and capacities of the defendants, as well as the skills of the experts involved in the trials. The students conducted themselves with a skill which compared well with that demonstrated by many, if not most, of the counsel who originally participated in the litigation of those cases. At luncheon that day, students sat at four-place tables, each of which had three students and a person such as a judge from the court of appeals, the late Dr. Winfred Overholser, superintendent of St. Elizabeths, or some other illustrious person involved in the development of the case law on mental illness in the District of Columbia.

Needless to say, this seminar generated an excitement which I have rarely seen duplicated. I am sure those students will never forget that experience, and all of them gained, among other things, a vivid image of the ways Judge Bazelon viewed psychiatric concepts and psychiatric expert testimony, as well as the way he viewed his role and function as a judge. In every class session Judge Bazelon's probing concern about the nature of psychiatric theory, data, and the way they should be presented in court was highly visible and evocative. It has always been clear to me that I learned as much as anyone in that seminar.

While Judge Bazelon was teaching with me, we established a series of seminar meetings among the University of Pennsyl-

\footnotetext{
${ }^{8}$ For his views on delinquent behavior, see F. Red \& D. Wineman, Children WHO HATE (1951).

${ }^{9}$ Wells v. United States, 239 F.2d 931 (D.C. Cir. 1956); Overholser v. Leach, 257 F.2d 667 (D.C. Cir.), cert. denied, 359 U.S. 1013 (1958); Carter v. United States, 252 F.2d 608 (D.C. Cir. 1956).
} 
vania Law School faculty. Those members who wished to attend met approximately every second or third week at my home for an evening bull session with Judge Bazelon and myself. Drawn by the presence of Judge Bazelon, most attended fairly regularly, and it was in this situation that I first came to appreciate the skill of Judge Bazelon as a persuader-negotiator. My faculty colleagues could hardly be characterized as timid or reluctant debaters, and it fascinated me to observe the way in which the Judge could get them to consider his fairly unusual and unorthodox approaches to such issues as criminal responsibility. Those faculty seminars provided an interesting supplement to the activities of that year, and foreshadowed the considerable skill which Dave Bazelon would come to deploy as a teacher.

In subsequent years, I have had many opportunities to hear Judge Bazelon lecture and discuss matters of interest to psychiatrists. His involvement with the substance of psychiatric information as it relates to law has become widely known throughout the world, and nearly every working psychiatrist has some familiarity with him and his ideas. Though he is often critical of the psychiatric profession, he never fails to catch its attention and make it seriously consider the problems he poses. In a recent issue of Psychiatric News, an article describing his lecture to the American Psychiatric Association entitled The Perils of Wizidry opened with the statement, "At its own invitation, psychiatry once again had its tail twisted by Judge David Bazelon of the U.S. Court of Appeals for the District of Columbia."10 The lecture reflected Judge Bazelon's continuing efforts to teach psychiatrists about the way their information is utilized by the legal system. The propositions he posed are similar to those he has raised consistently for years. The fact that he is still invited to participate in this "teaching" is testimony to the esteem in which he is held by the psychiatric profession, despite the fact that he often takes it to task. This esteem is so great that in 1969 he was elected President of the American Orthopsychiatric Association, an important professional group whose membership embraces psychiatrists, psychologists, social workers, teachers, and lawyers. When he was elected to that office he was added to the roster of a leadership-elite. ${ }^{11}$

\footnotetext{
${ }^{10}$ Psychiatric News, June 19, 1974, at 20, col. 1.

1 For a description of Judge Bazelon by a leading psychiatric educator, see Eisen-
} 
I had another opportunity to observe Judge Bazelon's teaching skill many years ago in a seminar at the federal hospital in Springfield, Missouri, where most of the government's competency-to-stand-trial evaluations were carried out. The subjects of the seminar included criminal responsibility and competency to stand trial, and those attending included such notables as Dr. Karl Menninger. The discussions made it clear that few of the psychiatrists present understood the legal questions which were central to the evaluations carried out by the hospital, while on the other hand, Judge Bazelon was very familiar with the psychiatric propositions put forward. For that reason, it was he who placed problems in appropriate perspective and I suspect that, had he not been there, the seminar would have been just one more example of communication failure between lawyers and psychiatrists.

Judge Bazelon has often reiterated that the only way the complex problems involving law and psychiatry can ever be resolved is for the members of both professions to understand each other's problems well enough that they can be appropriately considered by courts. For this reason, in addition to his work with psychiatrists, he has been involved in the development of learning experiences for the judiciary. During the course of our teaching collaboration in Philadelphia, I was involved in one of his efforts to bring psychiatric information to his colleagues on the bench. On this occasion he obtained two movies which explored institutional psychiatric care, and showed them to the Justices of the Supreme Court and to the judges of the District of Columbia court of appeals. Their content provided an opportunity for the judges to discuss some of the treatment principles involved. I would speculate that it has been necessary for Judge Bazelon to engage extensively in this kind of activity over the years, in order to enable his colleagues on the bench to plunge as deeply and as skillfully as they have into the many psychiatric issues with which their opinions have dealt. Judge Bazelon's leadership in developing this sensitivity is surely one of the reasons he will be held in high esteem for a long time to come. No other court has ever carried out such a meticulous dissection of the issues, nor provided so much information about how to deal appropriately with

berg, Judge David Bazelon, 39 Am. J. Orthopsychiat. 372 (1969). The essay also enumerates Bazelon's many honors and accomplishments up to the time of its publication. 
psychiatric matters. Its explicit formulation of a new rule for criminal responsibility is inconsequential as compared with the multitude of procedural questions with which it has dealt. ${ }^{12}$ This Article will do little more than allude to these cases, which have been discussed extensively in Judge Bazelon's many lectures and articles.

There can be little doubt that Judge Bazelon views himself as a judicial "activist." Examination of the many issues he has explored in his lectures will readily confirm this opinion. I would like to look at the substance of some of these views and react to them from the viewpoint of a psychiatrist.

\section{Observations About the Judicial Role}

Perhaps one of the most controversial issues dividing physicians and lawyers relates to the evaluation of medical opinions. This concerns not only the medical profession's involvements with litigation, but also its relationship to society in general. Physicians more than any other group of experts have resisted the notion that a nonexpert could have the capacity to look at their activities and make sensible judgments about them. This attitude comes into sharp visibility in relation to all expert medical testimony, but especially in relation to expert psychiatric testimony. Judge Bazelon, in his court opinions and lectures, has made many suggestions which could help resolve this problem, if they were better understood. Based on his observation that one function of a court is "monitoring the decisional process," 13 he has consistently and persistently pointed out the importance of having psychiatric expert witnesses describe the data which they have utilized in reaching their judgments in language sufficiently comprehensible to laymen so that the factfinders can decide whether or not the experts have skillfully and rationally carried out their work. He notes that courts evaluate everything else from environmental biology to nuclear physics. Why should they not do likewise with psychiatry? ${ }^{14}$ This proposition was stated ex-

12 Watson, Durham Plus Five Years: Development of the Law of Criminal Responsibility in the District of Columbia, 116 Am. J. Psychiat. 289 (1959). See also A. Goldstein, The INSANITy Defense (1967).

${ }^{13}$ Bazelon, Psychiatrists and the Adversary Process, Scr. AM., June 1974, at 18.

${ }^{14}$ See Bazelon, Implementing the Right to Treatment, 36 U. CHI. L. REv. 742, 743 (1969). See also Bazelon, supra note 13, at 18. 
plicitly in Carter $v$. United States, ${ }^{15}$ and later repeated in Washington $v$. United States. ${ }^{16}$ At least in the District of Columbia, any lawyer who presents expert psychiatric evidence in his case without clearly laying out the data from which the opinion was drawn stands a serious risk of reversal if the case goes to the court of appeals.

Judge Bazelon also notes that courts probably have to function in the role of "muckraker." 17 By this he means that courts should file constant complaints about society's shortcomings and its failure to deliver what it promises. ${ }^{18}$ This proposition is well illustrated in the landmark case of Rouse v. Cameron, ${ }^{19}$ which raised the question of right to treatment and which has led to a rapidly pyramiding literature, and very possibly some entirely new techniques of medical management. These matters will be discussed further below.

Finally, Judge Bazelon understands the fact that courts have the function of reconciling irreconcilable differences. ${ }^{20}$ Judges must fulfill society's need to have somebody who will "bite the bullet," and Bazelon's court has demonstrated over and over again its willingness to do so. In the area of mental health care there is a multitude of technical issues which everyone regards as difficult and presently not susceptible to scientific settlement. ${ }^{21}$ Nevertheless the District of Columbia court of appeals has dealt with these matters successfully in its opinions. The case law of that court reflects a kind of social experimentation in which

15252 F.2d 608, 617 (D.C. Gir. 1956).

16390 F.2d 444 (D.C. Cir. 1967).

${ }^{17}$ Bazelon, supra note 14 , at 749 .

${ }^{18}$ This point was made in an address delivered to the National Council of Juvenile Court Judges in Atlanta, Georgia on July 6, 1970. See Bazelon, Beyond Control of the Juvenile Court, 21 Juv. Cr. JudGes J. 42, 44-45 (1970).

19373 F.2d 451 (D.C. Cir. 1966).

${ }^{20}$ Bazelon, supra note 13 , at 19 .

21 For example: (1) what are the appropriate treatment methods for various types of mental illness at various stages of development and remission? (2) How do you handle the "shifting" levels of competency in patients undergoing psychotherapy? (3) What is the competency of a patient who is on anti-psychotic medication? (4) Can persons with the diagnosis of "personality disorder, anti-social type," be treated effectively? Under what conditions? (5) Can effective psychotherapy be carried out with a non-voluntary patient? (6) How do you handle the consent for treatment question with adolescents from ages thirteen to eighteen, when they wish to take a different course of action from their parents? (7) Can children who will have learning or behavior difficulties in the future be predicted? Can they be treated to prevent such a difficulty? (8) Can future homicidal behavior be predicted? How much over-prediction or underprediction will there be? Can such a proclivity be altered preventively? 
various hypotheses have been raised, considered, experimented with in various themes and variations, and then sometimes discarded, as was the Durham rule for insanity. If the holdings of that court had been given in a stark, conclusory form, they would not have been half as useful as they are. In the best common law tradition, Judge Bazelon and his brothers explore meticulously, and then explain how and why they arrive at their decisions. These opinions have been very useful in helping psychiatrists know what is expected of them in their courtroom participation. Just as effective expert testimony is free of technical jargon, these opinions have the merit of being comprehensible to nonlawyers, and so may be used by them to sharpen their participation.

\section{A. Lawyers, Judges, and the Community's Mental Health Activities}

Judge Bazelon's interest in psychological processes inevitably led him into discussions regarding the roles and behavior of lawyers, and to consider legal education in general. In his 1973 Marx Lectures at the University of Cincinnati, ${ }^{22}$ while discussing specifically the legal issues about the right to effective counsel, he put forward the idea that lawyers should broaden their approach to clients, in order to help them to deal with all of the problems which emerge during the unfolding of a case:

Someone in the system of justice must be concerned with the whole man, rather than just with whether he committed a particular act. That person is counsel. This is not to say that counsel himself must be a social worker psychologist, job counselor and the like. Rather, by being sensitive to his client's needs, concerned with him as a person and aware of available resources, counsel can bring the client to those resources. ${ }^{23}$

Knowing how to be helpful in these ways would not only be a great service to clients, but it would also help the attorney deal with the legal work. A lawyer must engage constantly in a datagathering process with his clients, and his psychological skill and understanding will either add to or subtract from his ability to make sense of their problems. Legal concepts such as mens rea,

22 Bazelon, The Defective Assistance of Counsel, 42 U. Cin. L. REv. 1 (1973).

${ }^{23}$ Id. 46. 
scienter, neglect, intent, knowledge, purpose, and a host of others all have psychological elements which must be understood if counsel is to deal with them effectively. ${ }^{24}$ Such understanding is especially important in such areas as family law, where it is common knowledge that counsel often function poorly. ${ }^{25}$

It is crucial that lawyers begin to acquire these skills. In fact, knowledge about interviewing technique is now so well established that in just a few years ineptitude in this area should be considered a basis for legal malpractice. Just as it may be negligent for a doctor to fail to discover a patient's illness, so it should be for a lawyer whose client comes in with a "diagnosible" problem and the finding is not made. Judge Bazelon's suggestion that lawyers expand their role is appropriate and highly desirable.

Having recognized the importance of these skills, lawyers still disagreed on the means of acquiring them. Only a few years ago it was argued vigorously that they could not be taught effectively in law schools, and that they were not an appropriate academic goal in any case. Because of this, such matters were left to be learned during the early years of law practice. ${ }^{26} \mathrm{Re}$ cent concerns about lawyers' professional behavior, however, coupled with a considerable demand from law students, have led to an increased interest in, and attention to, "clinical teaching" in the law schools. ${ }^{27}$ By 1972, with considerable financial support from the Council on Legal Education for Professional Responsibility (CLEPR), more than 105 of the 147 ABA-approved law schools had instituted courses which provide practice experience under teaching supervision. ${ }^{28}$ Although these programs are a step in the right direction, they still fall far short of providing the kind of learning experience which will help a lawyer

${ }^{24}$ In the trial context, Bazelon notes, "If an important issue escapes without exposure to that adversary process, then it is fair to say that the assistance of counsel has been ineffective, in the sense that it failed to produce a full-fledged public adversary trial." Bazelon, New Gods for Old: "Efficient" Courts in a Democratic Society, 46 N.Y.U.L. REv. 653, 671 (1971).

${ }^{25}$ See Pilpel, The Job the Lazuyers Shirk, Harpers Magazine, January 1960, at 67.

${ }^{26}$ For an excellent summary of these issues, see Boyer \& Cramton, American Legal Education: An Agenda for Research and Reform, 59 CoRnell L. Rev. 221 (1974).

${ }^{27}$ These concerns arose well before Watergate and its aftermath. However, the frightening spectacle of lawyer behavior in that episode has done nothing to lessen the concern. In fact, such concern provided the subject for many law school graduation addresses in 1974. I gave one such at the University of Pittsburgh. See Watson, The Watergate Lauyer Syndrome: An Educational Deficiency Disease, 26 J. LEGAL ED. 441 (1974).

${ }^{28}$ See Brickman, CLEPR and Clinical Education: $A$ Reviere and Analysis, in Crinical Education for the LAw STUdent 56, 60 (1973). 
become an "advocate for the whole man." In Judge Bazelon's words: "Only if counsel becomes a 'counselor' is there any hope for making the [legal] system's goal humanistic rather than mechanistic." 29

Counsel must see to it that his client's individual needs will not be overwhelmed by the system's own pressing need for administrative efficiency. Counsel must be the medium of reconciliation. . . . Such an expanded role may not be constitutionally mandated, but it may well be a moral imperative. It is the humane thing to do. ${ }^{30}$

When a law faculty moves in the direction of providing clinical education, however, it instantly encounters the need to reevaluate curricular content. At that point the tremendous diversification of law practice forces some kind of choice in content-focus, which in turn reinforces the controversial trend toward the specialization of the bar. Judge Bazelon is not overly disturbed by this. In the context of criminal practice, he stated:

In spite of the myth that all lawyers are generalists, criminal defense is a speciality. It requires a skilled trial advocate who is familiar with the criminal justice system, including not only the criminal code but also police and prosecutorial practices, the availability of local experts and private crime labs and the informal norms of the criminal courts. ${ }^{31}$

He urges that a system for certifying specialists in criminal practice be developed, ${ }^{32}$ and he endorses "the idea of moving students out of the classroom and into supervised programs of internship in the criminal justice system."33 If this clinical trend continues to develop, it will lead to the incorporation of skill training in interpersonal techniques as they relate to the counselor's role. ${ }^{34}$ Then legal education will not only prepare law students to deal with their clients as whole persons, but it will also help

29 Bazelon, supra note 22, at 45.

${ }^{30} \mathrm{Id} .46$.

${ }^{31}$ Id. 12.

${ }^{32}$ Id. $18-19$.

${ }^{33}$ Id. 19.

${ }^{34}$ See Watson, On Teaching Lawyers Professionalism: A Continuing Psychiatric Analysis, in Clinical Education for the Law Student 139 (1973); Watson, Professionalizing the Lauyer's Role as Counselor: Risk-Taking for Rewards, 1 LAw \& SOC. ORDER 17 (1969). 
them to be whole people themselves as they work with their clients. This could have a substantial positive effect on the very standards of professional behavior which have been so scrutinized in the light of Watergate and its aftermath. ${ }^{35}$

In analyzing the court's role in mental health activities, Judge Bazelon has made many observations about the "preventive" nature of the judicial system. For example, in a discussion about enlarging the judicial system, he said:

No matter how much we expand our judicial resources, the courts cannot be the primary agancy we rely upon to solve our problems. . . . But what the courts can do is take the time necessary to see to it that the other institutions are in fact doing what they are supposed to. This, I think, is the most important function of courts in a democratic society. ...

... The true measure of the quality of a judicial system is how many hidden problems it brings into public view and how well it stimulates the responsible officials and agencies into doing something about these problems. ${ }^{36}$

He made the same point in a talk to juvenile court judges:

The battle against juvenile crime can't possibly be won in court, even in the most enlightened court. That is only where we bring the worst casualties and hope that some, with good care, will survive, albeit with scars and crippling disabilities. The name of the game is Prevention, and that's the job for the institutions in the community that can help children without stigmatizing them, without labeling them delinquents and saddling them with a court record for the rest of their lives. The institutions that can handle that job may not exist. But it's up to you to call attention to the need, and not to go on pretending you can do the job yourselves. ${ }^{37}$

These comments about a court's preventive function parallel one of the important new social strategies of psychiatry, that of Community Mental Health. The touchstones of this approach are appropriate utilization of resources and the development of pre-

\footnotetext{
${ }^{35}$ See Watson, supra note 27.

36 Bazelon, supra note 24, at 654-655.

37 Bazelon, supra note 18 , at 44 .
} 
vention methods. Judge Bazelon has spoken of these concepts in several of his lectures to both psychiatrists and lawyers. In his New York University Law School address he said: "The way to make medical care more 'efficient' is to keep people from getting sick in the first place. And the way to make courts more "efficient' is to deal with the factors that cause people to commit their crimes." 38 He carried this point further in his Presidential Address to the American Orthopsychiatric Association in 1970. He described a "trouble center' . . . where people in the community can take all their problems, from an inadequate welfare check or a landlord's failure to make repairs, to a personality conflict at work or at home."39

The "trouble center" represents a conscious departure from the medical model for community mental health services. It is designed to give the center an image much more attractive to consumers than that of a traditional mental health facility. In this way the center may be able to reach deeper into the heart of the troubled community. If some of the people come in with problems outside the realm of traditional mental health concerns, the center can always call on lawyers or anyone else in the community who is willing and able to help. ${ }^{40}$

We see in these comments another example of the unconventional and creative Bazelon view of how the legal system might function in relation to the community's needs.

In exploring concepts of community mental health strategy, Judge Bazelon is not unaware of the need to delineate the respective roles of the various participants, as well as the rights of client-patients.

If we are going to lock up our old people, or our ugly people, or anyone else, we should do it without leaning on you [mental health professionals] ....

$\ldots$

$\cdots$

... The point is this: if you see someone drowning, and you think you can save him, you do it, but that

${ }^{38}$ Bazelon, supra note 24, at 660 .

${ }^{39}$ Bazelon, Follow the Yellow Brick Road, 40 AM. J. ORTHopsychiat. 562, 565 (1970).

${ }^{40} \mathrm{Id}$. 
doesn't mean that mental health professionals should become full-time lifeguards. ${ }^{41}$

He also applies these principles when he urges the desirability of keeping children within the school system for treatment, rather than spewing them out after applying some kind of psychopathological or legal label. ${ }^{42}$ If society and those concerned with mental health are to adopt his recommended course of action, many traditional roles must change. This in turn will stir the parties involved to resist. Dealing successfully with such resistance lies at the center of any successful project for social change. ${ }^{43}$

Finally, Judge Bazelon is sensitive to the uses of personnel in consultative roles, dedicated to warding off problems before they occur.

If it works, this kind of indirect action maximizes the effectiveness of the mental health professionals, who are in short supply, without leading society to rely too heavily on their expertise. I see in consultation the success of the Wizard of Oz. He helped the Scarecrow discover his own wisdom, the Tin Woodman his emotions, and helped the Cowardly Lion to know what courage really is. Dorothy was quite beyond his powers, because it took real magic to get her home to Kansas. But as for the others, he helped them to build on what they already had. ${ }^{44}$

This concept of consulation has been applied to enrich the function of lawyers in mental health settings. For example, one of Judge Bazelon's former law clerks, Professor Robert A. Burt, my teaching colleague on the University of Michigan Law Faculty, has been appointed to the Psychiatry Faculty in the Medical School. He frequently consults with us about the legal problems involving the troubled children and their families whom we treat at the Children's Psychiatric Hospital. Although this consultation is only one year old, it has already produced a marked improvement in the ways we help our juvenile patients and their families. At first, Professor Burt's presence and views were seen as a threat to the treatment process, a reaction which was totally predictable. But now his contributions are eagerly sought, freely

\footnotetext{
41 Id. 563-64.

42 Bazelon, supra note 18 , at $44-45$.

${ }^{43}$ Id. 45,50 .

44 Bazelon, supra note 39, at 566 (emphasis added).
} 
used, and enthusiastically applauded by staff and trainees alike.

Professor Burt is only one of an impressive list of experts on law and psychiatry who formerly served as law clerks to Judge Bazelon. This list includes Dean Abraham Goldstein and Professor Joseph Goldstein of the Yale Law School, and Professor Alan Dershowitz of the Harvard Law School. These men have developed extensive expertise in psychological matters as related to law, and they have each made substantial contributions to our understanding in this field. Certainly it does not strain credulity to attribute some of their interest and motivations to the work they did with and for Judge Bazelon. These, his "graduate students," bear witness to his pedagogical effectiveness; and, as all students do, they add to the lustre and stature of their teacher.

\section{B. Criminal Responsibility and Its Related Issues}

At least among behavioral scientists, criminal responsibility is probably the area of law for which Judge Bazelon is most widely known. The court's discontent with the insanity defense was telegraphed in Tatum $v$. United States, ${ }^{45}$ where it expressed discontent with the $M^{\prime}$ Naghten $^{46}$ test of insanity and observed that it would probably consider a change of rule in a future case. Then in 1954, Bazelon wrote his landmark opinion in Durham $v$. United States, ${ }^{47}$ reflecting the depth of his consideration and study of criminal responsibility and psychiatric theory and practice, an understanding which has now become quite extensive. In fact, an excellent handbook on psychiatric expert testimony could be assembled from his opinions (as well as those of his colleagues) which involve criminal responsibility and its collateral issues.

When the Durham test for criminal responsibility was handed down, it was clear that one of its main purposes was to facilitate and improve psychiatric expert testimony. As Judge Bazelon has noted, the previous tests of M'Naghten and "irresistible impulse" were seemingly clear legal definitions; however,

[t]here was just one small problem. The psychiatrists who had to testify about the defendant's mental condition insisted that the tests we were using had no basis

\footnotetext{
45190 F.2d 612 (D.C. Cir. 1951).

${ }^{46}$ Daniel M'Naghten's Case, 8 Eng. Rep. 718 (H.L. 1843).

${ }^{47} 214$ F.2d 862 (D.C. Cir. 1954).
} 
in reality. They said that mental illness could be disabling in a variety of ways that ought to amount to excusing conditions but that it virtually never destroyed the abstract capacity to distinguish right from wrong-or if it did, the psychiatrist had no way of knowing it. The court was finally persuaded that the existing tests were unsatisfactory, that they didn't correspond either to psychiatric reality or to commonly held notions of responsibility and excuse. But no one had a very clear idea of what to substitute for the old test. It would have been nice to find a new formula, one that more clearly expressed what was wanted as a matter of law, but we didn't quite know what was wanted. All we knew was that we needed more information about human behavior. We therefore decided to try a rule that sounded very simple. In Durham we said that a defendant would not be responsible if his act had been the product of mental illness. That left it to the psychiatrists to testify in the terms they knew best and to tell the jury as much as they could. ${ }^{48}$

It was hoped that his formulation would permit experts to present testimony in their own language, devoid of the strictures about which they had been complaining for so long. Regrettably, this did not occur. ${ }^{49}$ The language and content of psychiatric expert testimony in the cases tried in the District of Columbia continued to ring with all of its previous hollow formulations, and the court of appeals began to complain of it. For example, in Carter $v$. United States, ${ }^{50}$ the court stated:

Mental "disease" means mental illness. Mental illnesses are of many sorts and have many characteristics. They, like physical illnesses, are the subject matter of medical science. They differ widely in origin, in characteristics, and in their effects on a person's mental processes, his abilities, and his behavior. To make a reasonable inference concerning the relationship between a disease and a certain act, the trier of the facts must be informed with some particularity. This must be done by testimony. Unexplained medical labels-schizophrenia, paranoia, psychosis, neurosis, psychopathy-are not enough. Description and explanation of the origin, de-

\footnotetext{
${ }^{48}$ Bazelon, supra note 24 , at 657-58 (emphasis added).

49 See Watson, supra note 12.

50252 F.2d 608 (D.C. Cir. 1957).
} 
velopment and manifestations of alleged disease are the chief functions of the expert witness. The chief value of an expert's testimony in this field, as in all other fields, rests upon the material from which his opinion is fashioned and the reasoning by which he progresses from his material to his conclusion; in the explanation of the disease and its dynamics, that is, how it occurred, developed, and affected the mental and emotional processes of the defendant; it does not lie in his mere expression of conclusion. The ultimate inferences vel non of relationship, of cause and effect, are for the trier of the facts. ${ }^{51}$

This same idea is echoed in Bazelon's recent Scientific American article:

In the end, after 18 years, I favored the abandonment of the Durham rule because in practice it had failed to take the issue of criminal responsibility away from the experts. Psychiatrists continued to testify to the naked conclusion instead of providing information about the accused so that the jury could render the ultimate moral judgment about blameworthiness. Durham had secured little improvement over M'Naghten. ${ }^{\mathbf{5 2}}$

At another point in the same article, Judge Bazelon wrote:

What psychiatrists have not understood is that conclusory labels are no substitute in judicial proceedings for facts derived from disciplined investigation. Labeling a person "schizophrenic" does not make him so! Although the law must settle for an "educated guess," that guess is only as good as the investigation, the facts and the reasoning that underpin it. ${ }^{53}$

In a 1966 address given at University College in Dublin, Bazelon asked:

Why is the psychiatrist prone to give the court his diagnostic conclusion and little more? Basically, I often suspect, because he has little more to give. Our society has been unwilling to divert enough of its scarce re-

51 Id. at 617. The opinion was written by Judge Prettyman, although I suspect that this part of it might have come from the hand of Judge Bazelon. At least, as noted, it rings of concepts he has often articulated.

52 Bazelon, supra note 13 , at 21.

${ }^{53}$ Id. 20. 
sources to the study of those who are charged with crime. This goes to the root of our social system. Our psychiatrists may not be devoted entirely to the rich but they certainly are seldom familiar with the poor. Most defendants charged with crimes of violence are poor, uneducated, deprived, and segregated. Socially and professionally, most psychiatrists are in the middle class. Psychotherapy has been called the therapy of communication. But many psychiatrists cannot communicate with those accused with crime-and too often they lack the incentive to try.

Lack of knowledge is compounded by failure to admit ignorance. Doctors at one of our federal mental hospitals have often told me in private conversation that they do not have adequate staff and time to make a thorough study of an accused person's mental condition. Unfortunately, once transported to the courtroom they try to live up to our expectations of them-they won't admit that they do not have the answers for all the questions we ask. I sometimes feel that my psychiatrist friends who embrace Durham and testify beyond their knowledge have done more to warp the Durham concept than the conservative lawyers who oppose it. ${ }^{54}$

This latter point was echoed recently:

The sterility of the profession's response to Durham, I now conclude, was due to the fact that its observance was bound to make the psychiatrist's task in the courtroom much more demanding than before. The late Winfred Overholser, superintendent of St. Elizabeths, once told me that the breadth of information I envisioned being placed before the jury would require from 50 to 100 man-hours of interviewing and investigation; he declared that a public hospital simply could not afford it. If that were the case, I replied, psychiatrists should frankly explain on the witness stand that their opinions are thus qualified by lack of time and resources. It was no service to the administration of justice for them to create the false impression that they had learned substantially all that could be known about someone on the basis of study they knew was inadequate. ${ }^{55}$

\footnotetext{
5t Bazelon, Justice Stumbles on Science, 1 IRISH JURIST 273, $281-82$ (n.s. 1966).

5.5 Bazelon, supra note 13 , at 20-21.
} 
Judge Bazelon's court has also discussed the issue of who can testify about the facts of insanity. As far back as Carter it said:

In discussing as we have, expert medical testimony, we have not overlooked the admissibility of lay testimony. Lay witnesses may testify upon observed symptoms of mental disease, because mental illness is characterized by departures from normal conduct. Normal conduct and abnormal conduct are matters of common knowledge, and so lay persons may conclude from observations that certain observed conduct is abnormal. Such witnesses may testify only upon the basis of facts known to them. They may testify as to their own observations and may then express an opinion based upon those observations. Of course the testimony of a lay witness with training in this or related fields may have more value than the testimony of a witness with no such training. Also obvious upon a moment's reflection is the fact that while a lay witness's observation of abnormal acts by an accused may be of great value as evidence, a statement that the witness never observed an abnormal act on the part of the accused is of value if, but only if, the witness had prolonged and intimate contact with the accused. ${ }^{56}$

These are sound distinctions, and they conform well to psychological realities. The observations of lay observers are not only valid, but are very useful to corroborate or challenge the testimony of the psychiatric expert. Such lay observations should be given exactly the weight set forth in Carter. Some courts have lacked this kind of understanding, and have made a mockery of the distinction between expert and lay testimony on the question of insanity. ${ }^{57}$

36252 F.2d at 618.

${ }^{57}$ See, e.g., Commonwealth v. Carlucetti, 369 Pa. 190. 85 A.2d 391 (1952), where lay witnesses testified 14 years after a crime that they had noticed nothing unusual about the defendant. This was entered as rebuttal evidence against a psychiatric examination, made shortly after the crime, which described the defendant's psychotic condition. In fact, at the time of the competency examination (which led to a 14 year hospitalization), the psychiatrist noted that defendant's condition, which he called dementia praecox, had also existed at the time of the homicides. In this case the verdict of guilt and the death penalty were upheld by the Pennsylvania supreme court. See also the dissent of Souris, J., in People v. Wingeart, 371 Mich. 264, 274, 123 N.W.2d 731,736 (1963). The defendant's credibility was in issue, as it related to the defense of insanity. The trial court's opinion was upheld in the Michigan supreme court, in spite of the fact that all of the expert witnesses for both the prosecution and defense 
Judge Bazelon has also spoken on the closely related issue of who should be allowed to testify as an expert witness when the defense of insanity is raised.

In the Jenkins case, in 1962, spokesmen for the psychiatric profession betrayed a further misunderstanding of the role of the psychiatric witness that must have been widely shared among their colleagues. The trial court in this case had excluded the testimony of highly qualified and certified clinical psychologists, on the ground that "a psychologist is not competent to give a medical opinion." In the appeal to our court the American Psychiatric Association supported the lower court's decision. It asserted that in medical problems medical opinion can be the only guide. It chose to overlook the fact that the problem of criminal responsibility is not the exclusive terrain of psychiatry. I wrote the opinion for our court rejecting such guild mentality. ${ }^{58}$

Judge Bazelon is quite correct in his observation about the psychiatric profession on this point, and indeed the Association's lawyer should have instructed them that it was settled, long before Jenkins, that psychologists could testify on such matters. ${ }^{59}$ As Judge Bazelon has said, the opinion in the brief did tend to reflect the naive outlook of those members of the Association who have had little direct contact with the questions of criminal responsibility. This attempt to limit the nature of expert testimony, and its judicial rebuke, probably had at least a transient educational effect upon such members.

One of the principal criticisms which Judge Bazelon levels at the psychiatric experts who testify on criminal responsibility is that they tend to pre-empt the factfinding role. Despite a whole series of admonitions in the cases before Brawner, the experts continued to make this error. ${ }^{60}$

disagreed with it. Although it does not appear in the appellate opinion, the trial judge also interposed himself as an expert in the interpretation of the defendant's Rorschach responses. (This observation is based on the writer's personal participation in the case.)

${ }^{58}$ Bazelon, supra note 13 , at 21-22. The case referred to is Jenkins v. United States, 307 F.2d 637 (D.C. Cir. 1962).

${ }_{59}$ The naive attitude reflected by the amicus brief for the American Psychiatric Association in Jenkins led this writer and others to urge that the organization in the future refrain from filing such briefs. The large size of the organization and the simple logistical difficulties of soliciting views from membership greatly potentiate such ill-formed statements of position.

${ }^{60}$ See, e.g., Briscoe v. United States, 248 F.2d 640 (D.C. Cir. 1957). 
The Brawner formulation was designed in large part to end the expert's dominance over the question of moral responsibility. Psychiatrists will nonetheless still be able to take away the jury's function by presenting conclusory testimony. Thus they will testify that the defendant lacked capacity "as a result," just as under Durham they testified to whether the act was "the product" of a mental disorder.

Although no phrase will magically solve the problem of expert dominance, my own separate opinion in Brawner suggested the jury be instructed that a defendant is not responsible "if at the time of his unlawful conduct his mental or emotional processes or behavior controls were impaired to such an extent that he cannot justly be held responsible." This approach envisions that the jury will be provided with a broad range of information about the accused from a variety of sources including but not necessarily limited to psychiatrists. Other disciplines with special skills and knowledge in the field of human behavior would not be precluded from the opportunity to show the relevance of their data in the courtroom. Moreover, experts will be less likely to address the ultimate issue: whether the accused can be "justly held responsible." 61

Judge Bazelon is much too sophisticated to believe that mere reformulation of the test question will bring about the desired changes in expert behavior. Though the majority opinion tends to imply that the Brawner formulation (an adaptation of the ALI standard for nonresponsibility) will bring about such changes, there is an undercurrent of skepticism that runs throughout Judge Bazelon's opinion, epitomized by his comment that "while [e] generals are designing an inspiring new insignia for the standard, the battle is being lost in the trenches."62 Judge Bazelon has often stated that only a full awareness of the appropriate content and purpose of psychiatric expert testimony can enable courts to make proper use of it.

It is difficult to imagine that any body of law could more carefully delineate and explore the legal and social questions involved in the insanity defense than that which was developed in the District of Columbia after Durham, under the leadership of Judge

61 Bazelon, supra note 13 , at 21.

${ }^{62}$ United States v. Brawner, 471 F.2d 969, 1012 (D.C. Cir. 1972). 
Bazelon. Notwithstanding the incisiveness and eloquence with which these principles have been delineated, one has to conclude that in practice, their purposes have not yet been accomplished.

Psychiatrists testifying in the courts of the District of Columbia have generally failed to live up to the challenge presented by Durham. The hundreds of transcripts of trial proceedings I have read over the last ten years force me to the conclusion that they have been unwilling - or unable - to convey to the layman an understanding of why the accused acted as he did. Their testimony is frequently phrased in technical, stereotyped language that is not only unintelligible to the jury but also a substitute for hard thinking about the dynamics of the defendant's personality and his life history. ${ }^{63}$

What has been true in the District of Columbia has also been mostly true elsewhere. ${ }^{64}$ Since this is the case, would it not be logical to eliminate totally the defense of insanity?

It has long been apparent that the philosophy underlying the insanity defense creates confusion regarding the goals of the criminal law. From its beginning it created ambiguity in relation to definitions of mens rea, ${ }^{65}$ and this confusion has only recently been clarified in jurisdictions which have established a "bifurcated trial" to deal with it. ${ }^{66}$ However, the basic problems raised can be dealt with logically only with a fundamental alteration in the whole structure of the criminal law and its sentencing procedures.

${ }^{63}$ Bazelon, The Interface of Law and the Behavioral Sciences, 271 NEw ENG J. MED. 1141, 1143 (1964). This was Judge Bazelon's Lowell Institute Lecture paper, given at the Massachusetts General Hospital.

${ }^{64}$ Diamond, describing the problems of M'Naghten for psychiatrists and expressing doubt that Durham will alter this state of affairs, believes that the only way in which psychiatric evidence will improve is if it is utilized in relation to questions of mens rea. He believes that this will solve the "all or none" quality of any insanity defense, which adds to the confusion of psychiatric expert witnesses. See Diamond, Criminal Responsibility of the Mentally Ill, 14 STAN. L. Rev. 59, 66 (1961). Some of the tenor of this controversy may also be found in A. Goldsters, supra note 12, at 102 . I have had the opportunity to see, hear, and read the psychiatric testimony in many of these cases over the years, and for the most part neither the experts nor the lawyers involved give much indication of having learned the lessons of the Durham line of cases.

${ }^{65}$ See Dixon, A Legacy of Hadfield, M'Naghten and Maclean, 31 AusTr. L.J. 255 (1957).

${ }^{66}$ See, e.g., Dix, Mental Illness, Criminal Intent, and the Bifurcated Trial, 1970 LAw \& Soc. Order 559 (1970); Louisell \& Hazard, Insanity as a Defense: The Bifurcated Trial, 49 Calif. L. Rev. 805 (1961); Comment, Psychiatry v. Law in the Pre-Trial Mental Examination: The Bifurcated Trial and Other Alternatives, 40 FordHaM L. REv. 827, 848-68 (1972). 
Such proposed changes have been well described by the British criminologist Baroness Wootton and by the American criminologist Paul Tappan. ${ }^{67}$

Several legally sophisticated psychiatrists have urged that psychiatrists should withdraw completely from the trial aspects of insanity and other psychological questions, and limit their participation to the posttrial sentencing and treatment aspects of the criminal justice system. ${ }^{68}$ This would cripple the insanity defense and, in all likelihood, would lead to its elimination. Goldstein and Katz analyzed abolishing the insanity defense altogether, and arrived at a mixed conclusion. ${ }^{69} \mathrm{I}$ am of the opinion that unless and until there is the kind of extensive remodeling of the criminal law suggested by Wootton and Tappan, the defense of insanity provides a useful window for the community into the nature of the social and psychological problems it seeks to deal with through the criminal law. If the defense is to fulfill this function, psychiatric experts must continue to participate at the trial level.

The defense of insanity only rarely succeeds, and then hardly ever for purely rational reasons. More often than not, the "craziest" people, who commit the most heinous acts, are the least likely to be successful with the defense. They succeed in frightening the community so thoroughly that all of its atavistic and retributive impulses are mobilized fully, and a verdict of guilt generally results.

Even though the insanity defense fails in a given case, if the defense is presented adequately the court and the community are confronted with the nature of the psychological forces which lead to criminal behavior. In this way, ever so slowly, the social approach to deviance can change and, perhaps in a hundred years or so, a rational theory for the treatment of deviants, such as that laid out by Wootton, can become a reality.

As I read and reread Judge Bazelon's writings on the subject of the insanity defense, I was curious about his views regarding

\footnotetext{
${ }^{67}$ See P. Tappan, Crime, Justice, Correction (1960); B. Wootton, Crime and the Crminal. Law (1963).

${ }^{68}$ See S. Glueck, Crime and Justice 248-80 (1936); S. Halleck, Psychiatry and the Dilemmas of Crime 205-28 (1967); K. Menninger, The Crime of Punishment 1 12-42 (1966); P. Roche, The Criminal Mind (1958); T. Szasz, Psychiatric Justice (1965); G. Zilboorg, The Psychology of the Criminal Act and PunishMENT (1954). (1963).

${ }^{69}$ Goldstein and Katz, Abolish the "Insanity Defense"-Why Not?, 72 YALE L.J. 853
} 
its future. Although I could find few explicit comments on this point, it seems clear that he tends to see this defense as having ongoing educational value to the community, notwithstanding its logical incongruities. In speaking in general about the input of science to legal thinking in his Dublin address, Judge Bazelon made the following comments:

For a lawyer and a judge, I have had a unique opopportunity to observe and participate in the discussions of some of these scientists. The initial, albeit perhaps misguided, enthusiasm of behavioral scientists for Durham either pulled or propelled me into their midst. I have not yet extricated myself. So I sit by and hear scientists explain the discovery of the genetic code. I hear them expound on the factors which affect how a human being will develop even before he is born. At the same time I learn that identical cells will react differently depending on the environment in which they are placed. These sciences are now bringing in clues to even more revolutionary findings, as far as ethics and law are concerned. The use of drugs to tranquilize, or otherwise to influence the mind, will have far reaching implications for our concepts of responsibility and justice.

Full of such facts and speculation, I come back from meetings with scientific groups at the Salk Institute for Biological Studies and various other institutions and I try to concentrate on the cases which come before me for decision. But I must forget most of what I learned from the sciences of behavior when I judge the behavior of the real human being who comes before our court.

I'm reminded of the story of the ancient king who asked a fakir for the formula he was selling throughout the kingdom for turning sand into gold. Realizing that he had better not admit his fraud, the fakir said: "There are ten steps which must be executed with absolute precision for success." Then he went on to explain that the first step required a room with specifications in terms of fractions of inches; and that each of the next eight steps was increasingly precise and difficult. Then he said that even if all nine instructions are followed, there could be no success unless the last and tenth instruction was faithfully observed, namely, that while engaged in these difficult calculations "you must not think of a hippopotamus." 
The hippopotamus ruined a perfectly good recipe for making gold out of sand. It seems to me that the criminal law will find it harder and harder not to think about the science explosion. I sometimes wonder how long it will be before the orderly processes of the criminal law are shaken by our expanding knowledge of the human being and his behavior. And I ponder over whether the biochemist will fare any better in the courtroom than does his co-worker, the psychiatrist.

The relations between the individual and society are too important to be left to the scientists alone. The criminal law has a role to play. It enforces society's expectations. One might even say that the purpose of the criminal law has been to administer the effects of our disappointed expectations. The law has traditionally sought to reduce the gap between society's expectations and the incapacity for some to fulfill them by minimizing recognition of that incapacity. M'Naghten seems designed to do precisely this. We put our expectations in one compartment and our learned sense of reality in another. There is little communication between the two. We are fearful that explanation may be taken as absolution. Yet my contention is the opposite. For I contend that personal responsibility is linked, indeed locked, to understanding; and that expectations are altered by a growing knowledge of the springs of human conduct, so utilitarian morality will give way to a humane yet practical morality, based on such understanding. A serious inquiry into the defendant's criminal responsibility can provide the catalyst for change. ${ }^{70}$

In his James Madison Lecture on Constitutional Law at New York University in 1971, Judge Bazelon said, when talking about the development of the law of insanity:

But all of this takes time. The issue of criminal responsibility takes more time to try in 1971 than it did in 1954 and is raised in more cases. We could return to our old "efficiency" by shoving our problems back under the rug. If we did that, we would not only be turning our backs on whatever we may have learned in the past seventeen years, but would also be abdicating our most im- 
portant role. For the heart of the judicial process is by its very nature inefficient. The way towards "efficiency" in the courts is not to shortcut judicial procedures in order to dispose of more cases in less time. Such a solution is equivalent to a surgeon's omitting time-consuming diagnostic procedures and simply operating at random on whatever patients are brought before him. He could certainly process more patients this way, but few of us would think his performance had been improved. The way to make medical care more "efficient" is to keep people from getting sick in the first place. And the way to make courts more "efficient" is to deal with factors that cause people to commit their crimes. ${ }^{71}$

Quite clearly, Judge Bazelon is willing to spend judicial time to open up and clarify complex social and psychological issues. This attitude about the nature of the judicial function is found over and over again in his writings. For example, in his Lowell Institute Lecture of 1964 Judge Bazelon said:

The law's demands on psychiatry may seem less onerous if the expert witness sees that his purpose is not merely to testify but to educate-that he cannot really accomplish one without the other-and if he sees that the information he makes available to those who have to pronounce a moral judgment is also to be used in later rehabilitative efforts. ${ }^{72}$

The conclusion would seem to be that Bazelon would not wish to eliminate the defense of insanity, at least at the present time. ${ }^{73}$ Before leaving the subject of criminal responsibility, I would like to make some observations about the general effect which Judge Bazelon has had on the psychiatric profession. Though few psychiatrists are sophisticated about the law of criminal responsibility (and most share a substantial naïveté about all law), nearly all of them have heard of Judge Bazelon and have read or heard his lectures. Whenever Judge Bazelon speaks at a psy-

${ }^{71}$ Bazelon, supra note 24, at 660 (emphasis added).

72 Bazelon, supra note 63, at 1144 .

${ }^{73} \mathrm{He}$ made the point in another lecture that we should not eliminate the defense, because retaining it forces the community to examine the causes of crime, and therefore such psychiatric information belongs in the trial. "If we first find guilt and then promise to provide treatment for the person in spite of his guilt, we turn away from the question which should concern us most-the causes of criminal behavior." Bazelon, The Future of Reform in the Administration of Criminal Justice, 35 F.R.D. 99, 112 (1964). 
chiatric meeting, his presentation must be scheduled for the longest hall available, and it will be packed. At the very least these contacts have stirred interest in the relationships and obligations of psychiatry to the legal process. The reasons for this are clear. Judge Bazelon has done what every successful interdisciplinary teacher must do; he has mastered the language of the listener. Although his challenges are sharp and his criticisms often biting, they have a sufficient ring of truth so that we must listen. Judge Bazelon entered our arena through the issue of the insanity defense, a question with which we had some real or imagined familiarity. Since then, he has taken us into an ever-widening set of legal-psychiatric issues. Partially because of this, the literature on law and psychiatry has progressively moved away from the narrow focus of criminal law issues toward a multitude of new and important social questions. The lessons and frustrations experienced while working with the insanity defense have already been encountered in the newer areas of concern, and because of Judge Bazelon's elucidations and admonitions perhaps some of the earlier mistakes will be avoided.

\section{The Right to Treatment}

The concept of the involuntarily hospitalized mental patient's "right to treatment" was formulated first by Morton Birnbaum, ${ }^{74}$ who set forth the notions that have now been elaborated extensively and which are beginning to become the subject of statutes $^{75}$ and judicial opinions. However, the first judicial consideration of the right to treatment question arose in Rouse $v$. Cameron $^{76}$ in an opinion written by Judge Bazelon in 1966. The case involved a patient in St. Elizabeths Hospital who had been civilly committed following a finding of not guilty by reason of insanity. He received little help beyond what has come to be known euphemistically as "milieu therapy."77 When this case

${ }^{74}$ See Birnbaum, The Right to Treatment, 46 A.B.A.J. 499 (1960).

${ }^{73}$ E.g., Alaska Stat. \& 47.30.130(a) (1971); D.C. Code ANN. \$ 21-562 (1973).

${ }^{76} 373$ F.2d 451 (D.C. Cir. 1966). See also Creek v. Stone, 379 F.2d 106 (D.C. Cir. 1967) (right to treatment doctrine applied to juvenile homes).

77 Although this expression is now loosely used to describe any kind of inpatient psychiatric treatment, its concepts of total psychological management of the hospital environment were pioneered by Dr. Maxwell Jones and reported in M. Jones, THE Therapeutic Community (1953). His treatment groups included prisoners of war and one made up of patients with "stress neuroses" induced by work in industry. The 
came to the Court of Appeals:

The American Psychiatric Association responded to Rouse with an adamant statement of what I must call professional mystique: "The definition of treatment and the appraisal of its adequacy are matters for medical determination." This declaration ignored the explicit message in Rouse that the court does not presume to assess the quality of anyone's performance, unless that performance is patently arbitrary and capricious. As in all administrative law, the task of the court is to ensure that the administrative process itself controls abuse of discretion, that a factual record is established, that alternatives are considered and that reasons for decisions are set forth.

The instant opposition to Rouse was a clue to a deeper discordance between the professional and the judicial outlook. Plainly the profession was blind to or was concealing the conflict between the imposition of treatment and the human and civil rights of patients. In the view of most members medical decisions are by definition made in the best interests of the patient. If a physician says a man is sick, he must be sick; if he says the man must be treated or confined, that must be what is best for him. Such bootstrap reasoning comes under scrutiny only when, in the case of psychiatric prescriptions, it calls for involuntary treatment. The patient's interest in release, in less restrictive confinement or in adequate treatment cannot be matters solely "for medical determination."78

treatment goal in these groups was to achieve a level of socially appropriate behavior by means of learning from the totally managed environment, one which encompassed work, ward maintenance, and recreation, as well as social role activities. Such a program also included the development of a ward governance body with a predominant patient representation. These groups relied heavily upon patients helping each other with staff acting mainly as guides and consultants. All activities are aimed toward helping patients learn skills for living in the community and not to adapt to the hospital.

Regrettably, as noted above, this treatment concept is often coopted and perverted to label any institutional setting in which therapeutic change is allegedly sought; four walls and a staff do not a therapeutic community make. It takes great sophistication and therapeutic competence to facilitate and catalyze the development of a therapeutic milieu or community; mere labeling, as always, will not suffice. See also M. Jones, Therapeutic Community Principles, in II Law, Psychiatry and the Mentally Disordered OFFENDER 102 (L. Irving \& T. Brelje eds. 1973).

${ }^{78}$ Bazelon, supra note 13 , at 22. This theme is also explored in Bazelon, The Right to Treatment: The Court's Role, 20 Hosp. \& Community Psychiat. 129, 131 (1969). 
Rouse raised considerable controversy, and resulted in vigorous discussions between psychiatrists and lawyers over the issue of legal intrusion into medical practice. This interchange has had an excellent pedagogical effect upon the psychiatric profession, and probably has also led to a deepening understanding on the part of the legal profession about some matters concerning psychiatric practice. Many psychiatrists saw the court's action as an ominous portent, an intrusion which would destroy the doctorpatient relationship and grossly inhibit the therapeutic process. Since Rouse would be applied, however, primarily to patients in large state institutions, where physicians tend to see their patients briefly and at infrequent intervals, it is difficult to conceive that such a result would be of any great consequence. In Judge Bazelon's words:

Bringing these matters into court does not impose an artificial adversary relationship between the patient and his keepers; it reflects an adversity that already exists. This proposition comes as a surprise, of course, to the psychiatrist engaged exclusively in office practice and to his voluntary patient. In the public sector the adversity of interests that confronts the psychiatrist and his involuntary patient-although it does not encompass the entire relationship-must be recognized as an inescapable reality. ${ }^{79}$

In another place he said:

Moreover, to the extent that the legislature commits the community to providing treatment for patients involuntarily hospitalized for that purpose, precisely the same considerations suggest that the legislature may also commit itself to provide the standards and machinery necessary to assure the reality of treatment. ${ }^{80}$

Rouse did not go far toward making these standards explicit. However, in the Alabama case of Wyatt v. Stickney ${ }^{81}$ the Rouse goals were resolved into three general criteria for establishing adequate treatment: an environment which provides humanely for physi-

\footnotetext{
79 Bazelon, supra note 13 , at 22.

${ }^{80}$ Bazelon, supra note 14 , at 745 .

81334 F. Supp. 1341 (M.D. Ala. 1971), final orders issued, 344 F. Supp. 373, 379
} (M.D. Ala.), supplemented, 344 F. Supp. 387, 395 (M.D. Ala. 1972). 
ological and psychological needs; a minimally adequate staff; and individualized treatment plans that set goals which are periodically reviewed. Bazelon anticipated these propositions in two 1969 papers, ${ }^{82}$ and urged them in testimony before the Pennsylvania legislature when it was considering mental health code modifications. ${ }^{83}$

Judge Bazelon is acutely aware of the various social-psychological forces which must be dealt with when a question such as right to treatment is approached:

The judicial need for a right to treatment arises primarily because we have hundreds of thousands of patients residing - voluntarily or not-in state institutions. In the vast majority of cases, even if we resist the temptation to call these unfortunates "prisoners," it is fairer by far to refer to them as "residents" than as "patients." Rare is the person with a physical ailment who remains a hospital patient for years on end. While an equation between mental and physical illness is simplistic, any layman must view with skepticism the description as "patients" of persons who remain for years in our isolated, often overcrowded public mental institutions. The fact that such skepticism took so long to surface testifies to the capacity we all share to mask harsh realities with gentle words.

The public tolerance for euphemism may finally have exhausted itself in this area. There are powerful currents at work upon the entire structure of society's response to the mentally ill. ${ }^{84}$

Judge Bazelon has often commented upon the dangers of leaving this important set of questions to the mental health professionals alone. He notes that "[w]hereas peer review is a much praised and not much observed principle of the medical profession, it has been largely foreign to the practice of psychiatry." 85 He made the same point in describing his visit to Russia to ob-

${ }^{82}$ Bazelon, supra notes 14,78 . "The most important facet of the right to treatment is not that the hospital does something for everyone, but that it does the right thing for the right patient." Bazelon, supra note 14 , at 746 .

${ }^{83}$ Bazelon, Rights of Mental Patients to Treatment and Remuneration for Institutional Work: Prior Court Decisions and Legislation, 39 PA. B.A.Q. 543 (1968).

${ }^{84}$ Bazelon, supra note 14 , at 752-53.

${ }^{85}$ Bazelon, supra note 13, at 22. 
serve Soviet methods of psychiatric treatment. ${ }^{86}$ Since the time of Judge Bazelon's visit, the Soviet government's utilization of psychiatric hospitalization for political purposes has become more visible and his warnings about the risks appear to have been substantiated. ${ }^{87}$

Exploration of the medical, legal, and moral issues involved in the involuntary hospitalization of the mentally ill has received much stimulation from Judge Bazelon. His continuing interest, coupled with great psychological sophistication, has done much to bring these important issues before the legal and psychiatric professions as well as the public.

\section{Criminal Law}

Judge Bazelon's approach to criminal law problems is greatly influenced by his conviction that society's first concern should be to discover why a crime was committed, and not simply whether or not to punish. He is not so much concerned about the number of persons whom the law might find not responsible for whatever reason, but rather how any person who commits a criminal act should be handled in order to minimize the likelihood of future criminal behavior. Thus he states:

[Some penologists] suggest that the proper place for the consideration of complete psychiatric evidence is in and after sentencing, not in the determination of guilt. Hold the man responsible on the basis of M'Naghten; then remove the gag from medical testimony to decide what treatment he needs. There is sweet reasonableness in this view. And it has the added attraction of being easy. It withdraws from the community a difficult and troubling issue. But that issue, in my judgment, is one which the community has not only a right but a duty to consider. If we first find guilt and then promise to provide treatment for the person in spite of his guilt, we turn away from the question which should concern us most-

${ }^{86}$ See Bazelon, The Law and the Mentally Ill, 125 Am. J. Psychiat. 665, 669 (1968):

I was troubled by the assumption that the state has the right to intervene in the lives of its citizens to make all of the decisions on health care. The Russian system, for all its accomplishments, depends upon and reinforces a social system which is difficult for an American to accept.

${ }^{\mathbf{8 7}}$ For a psychiatrist's response to this practice, see Weinsten, Psychiatrists and Political Torture, 131 AM. J. Psychiat. $721-22$ (1974) (letter to the editor). 
the causes of criminal behavior. That is the question toward which Durham is directed. Even if our prison system were transformed, I should still be opposed to finding guilt regardless of moral responsibility, on the theory that the accused would be "treated" in prison. I think the success of efforts to treat the individual offender depends on the community's awareness of his needs-of how he came to act as he did. And the best available means for generating such awareness is to provide as much of this information as possible to the communityin-camera-to the jury, which will be forced to consider it seriously if it is required to assess the defendant's responsibility. I want the public, and not just the professionals, to know what caused the accused's behavior, so that they can have some idea of what is required not only for treatment but for the prevention of like cases. ${ }^{88}$

In taking this view, he joins many behavioral theorists, ${ }^{89}$ as well as such unusual judges as the late Jerome Frank. ${ }^{90}$

Fundamentally, Judge Bazelon always seeks to make the criminal justice system more humane and responsive to the rights and needs of individuals. He believes that a civilized society must have a humane system for dealing with its deviants, or it risks an erosion of all its human values. ${ }^{91} \mathrm{He}$ always favors these values over any consideration of efficiency. ${ }^{92}$ While readily conceding the need for improving the courts' speed and effectiveness,

${ }^{88}$ Bazelon, supra note 73, at 112-13.

${ }^{89}$ See sources cited in note 68 supra. See also Watson, A Critique of the Legal Approach to Crime and Correction, 23 LAw \& Contemp. Prob. 611 (1958).

${ }^{90}$ See J. Frank, Law and the Modern Mind (1936).

${ }^{91}$ See Bazelon, supra note 22, at 5:

Further, by advocating criminal justice reforms solely in the interest of crime reduction, we lose sight of our legitimate interest in justice for its own sake. Civilized society must have a humane criminal justice system which treats defendants with understanding and insight-regardless of how much or how little that system affects the crime statistics.

Later, while speaking of the right to effective counsel. he said:

Good defense work may well take more of the court's time. That is the price we pay for constitutional protections. If society believes in those protections, it will have to pay the price in terms of increased expenditures for the criminal justice system.

Id. 24.

${ }_{92}$ For a discussion dealing with some aspects of this issue, see Comment, Equal Treatment in the Enforcement of the Criminal Lau: The Bazelon-Katzenbach Letters, 56 J. CRIM. L.C. \& P.S. 498 (1965). A hair-raising description of a very "efficient" system of justice may be found in A. Solzhenitsyn, The Gulag Archipelago (1973). 
Judge Bazelon believes that "[i]t is a false efficiency indeed that speeds up the criminal process in order to speed up an unrehabilitated defendant's return to the streets."93 As he notes, "[i]nitially the tentacles of incipient totalitarianism seize only the scapegoats of society, but over time they may weaken the moral fibre of society to the point where none of us will remain secure."94

One aspect of Judge Bazelon's writings of particular interest to a psychiatrist is the frequent recognition of the importance of the psychological factors which underlie society's responses to crime. He knows that these forces must be dealt with if any kind of social change is to be effected. In the context of criminal law, one of the most important factors is the emotion of aggression, not only in the deviant behavior of defendants, but also in the reactions of judges, juries, and lawyers, because of man's capacity to identify with others. In one of his many references to this subject, Bazelon wrote:

Somewhat to my amazement, a few theorists of the criminal law have now come out into the open and argued that besides its two generally accepted purposesreformation and deterrence-a third rationale of the criminal law, vengeance, is also valid. Most of us still prefer to clothe our retributive instincts in the garb of deterrence. But we are being told that, since retribution is a "natural" human instinct, it is right and necessary for society to vent its feelings on the defendant. All agree that the individual must not give way to these feelings. He may not personally avenge a murder or even take his own life. A life for a life is acceptable, it seems, only if we all join in the taking. I hope the law has a less emotional, more rational and more moral base. True, we all have aggressive, punitive urges. But should the criminal law carry them out? Many people believe that international conflict begins with and feeds upon our aggressive impulses but few would advocate war. Awareness of our aggressive instincts should help us to refrain from aggression not to commit it collectively. ${ }^{95}$

His court's awareness of this human capacity and its influence on decisionmaking led to the development of the important rule of

\footnotetext{
${ }^{93}$ Bazelon, supra note 24, at 665 .

94 Bazelon, Lau', Morality, and Civil Liberties, 12 U.C.L.A.L. Rev. 13, 28 (1964).

9s Bazelon, supra note 73, at 107.
} 
Lyles $v$. United States ${ }^{96}$ that the jury must be informed of the results of finding a defendant not guilty by reason of insanity. Although he dissented from the holding in Lyles, Judge Bazelon concurred in that portion of the opinion, ${ }^{97}$ observing that when jurors do not know that such a person will be confined in a hospital until he is no longer dangerous, fear will mobilize all of their self-protective punitiveness, which may then cause them to find guilt. Although the precise nature of a jury's thought processes is not known, the court's opinion is completely logical, and very likely this fear would operate in the jury's decisionmaking. Judge Bazelon always comes back quickly to the absolute necessity of ensuring that the legal system does not do avoidable and inappropriate harm to the individual.

In a sense the entire system of criminal jurisprudence is "symbolic," since every part of it stands for something more than itself, namely, the preservation of the worth of each individual in a society of individuals. If we are to be true to our heritage at the same time that we struggle with the problems which beset us, we must deter not only crime, but also the debasement of the individual. ${ }^{98}$

This quotation is a fitting summation of Judge Bazelon's views of how the criminal justice system should work.

\section{E. Juvenile Courts and Children}

Through the years, Judge Bazelon has been closely involved as both student and educator with various organizations concerned with children. In one of his most recently published papers he nicely summarized his views on the social, psychological, and legal problems of the young. ${ }^{99}$ In this lecture, presented at the annual meeting of the American Academy of Child Psychiatry, he warned child psychiatrists against falling into the same social trap earlier encountered by adult psychiatrists-endeavoring to perform tasks and solve problems for which they had no capacity. He argued that only if they avoided this temptation could they fulfill the roles for which they were equipped, and at

:16 254 F.2d 725 (D.C. Cir. 1957) (en banc), cert. denied, 356 U.S. 961 (1958).

i7 Id. at 734 .

:18 Bazelon, supra note 94 , at 28 (footnote omitted).

"se Se Bazelon. "The Problem Child"-Whose Problem?, $13 \mathrm{~J}$. AM. Acad. Child PsYchiat. 193 (1974). 
the same time keep the pressure on society to solve the causes of maladjustment, delinquency, and poverty.$^{100}$ In this same lecture, he delineated clearly the conflict of interest problems which often beset psychiatrists when they work for a school, a hospital, or a court, and are asked to make a diagnostic judgment about their patient for the purpose of some legal disposition. ${ }^{101}$ The point is not a new one for Bazelon. He made it several years earlier in an address to juvenile court judges:

First of all, immature and authoritarian parents use the court's jurisdiction as a threat to hang over their children, a way to get out of their own obligation to work with their children and even to "get their own way" in a specific conflict with their children. The tired and apathetic ones readily abdicate their parental roles, simultaneously relieved and lulled by the promise that the problem can be handled by the juvenile court. ${ }^{102}$

Both of these admonitions are aimed at the much criticized procedure of attempting to solve problems by applying a label. Such facile maneuvers only serve to hide important matters from view. ${ }^{103}$ At most they result in shuffling the child from one inadequate evaluation agency to another and never get to the issue of providing for his fundamental needs for help or treatment. ${ }^{104}$

One of the principal vents through which children are extruded into social limbo is a finding of truancy. All too often these children have been left far behind in the academic wake of their peer group because the schools did not identify and respond to their specific deprivations and needs. Then, because they failed to enjoy school and profit from it, they avoided the pain of their scholastic humiliation, stayed out of school, and were expelled for truancy. "To end this syndrome, we put them in institutions where they usually get less schooling than if we had left them alone to skip school intermittently. Our local detention home gives one

${ }^{100}$ He might also have added that this could help them avoid what happened to the juvenile court movement with its promise of treatment and rehabilitation.

101 Bazelon, supra note 99 , at 195.

102 Bazelon, supra note 18 , at 43 .

${ }^{103}$ For a critique of such labeling by one of its most vociferous psychiatric opponents, see T. Szasz, The Myth of Mental Illness (1961). For a legal statement, see Carter r. United States, 252 F.2d 608 (D.C. Cir. 1956).

${ }^{104}$ See Bazelon, supra note 99, at 195. 
and one-half hours of schooling daily, and the regular public school system doesn't even give credit for it."105 This leads Judge Bazelon to conclude that it should not be possible to refer children out.of the school system, ${ }^{106}$ a view that some school systems at long last are beginning to adopt. In Michigan, for example, school districts are now required to provide school facilities for all children of compulsory school age, without regard to the nature or severity of their problems. ${ }^{107}$ Many school districts will resist such expensive alternative classroom programs. But the higher cost of the alternative programs will probably increase the pressure to keep children in the regular classrooms, which would be all to the good. Over time this will necessitate different classroom approaches and an earlier diagnostic effort to locate the children who are beginning to have problems, so that efforts can be made to prevent those problems from growing. ${ }^{108}$ If the community is forced to take this direction, its own desire for good education will press it toward getting children what they need at the earliest possible moment. This will hopefully initiate movement toward the kind of dispositional test for all children with problems proposed by Goldstein, Freud, and Solnit-that of "the least detrimental alternative available." ${ }^{109}$ This standard, as they point out so effectively, has the advantage of keeping decisionmakers fully aware that when they propose to provide a child with anything other than a normal family setting, it will be no utopian solution, but rather a choice between the least of the available evils.

Judge Bazelon reserves some sharp criticism for the grossly illogical decisions made about children in juvenile courts. In commenting on Morris Kent's case, ${ }^{110}$ the first juvenile court case to be considered by the United States Supreme Court, he observed:

So, without appointing a lawyer, without consulting

105 Bazelon, supra note 18 , at 44 .

106 Id. 45.

${ }^{107}$ Mich. Comp. Laws ANN. $\$ 340.77$ la (Supp. 1974).

108 This is what social psychiatrists call a "primary prevention" program. Such programs are aimed at complete avoidance of an emotional problem. "Secondary prevention" is a program directed to limiting and curing an existing emotional problem. "Tertiary prevention" is aimed at limiting the effects of an emotional problem. G. Caplan, Principles of Preventive Psychiatry 16-17 (1964).

109 J. Goldstein, A. Freud \& A. Solnit, Beyond the Best Interests of the Child 53-64 (1973).

110 Kent v. United States, 383 U.S. 541 (1966). 
Morris, or his family, the judge "waived" his court's jurisdiction over Morris so that he could be tried as an adult criminal in the United States District Court. There, the jury found him guilty of housebreaking and robbery, although it acquitted him by reason of insanity on the rape charges. This surprising verdict of simultaneous responsibility and non-responsibility for his crime led to a strange sentence. The criminal court judge sent Morris to a mental institution until he could recover his sanity. After that, when he had become a changed person, but a person mentally qualified to pay penance for the crimes of the previous person, he would serve a sentence of 30 to 90 years. ${ }^{111}$

He urges upon the judiciary the same constraints he presses upon the psychiatric profession-do not offer what you cannot provide in regard to treatment, and at least provide children with the protection of due process so that they do not end up receiving the worst of both the legal and the treatment worlds. ${ }^{112}$ In the same paper Judge Bazelon described what he flatly called bigotry, an attitude he finds not uncommon in the judicial treatment of juvenile offenders. He attributes such bigotry to the prevalent class differences between juvenile court judges and the children who appear before them. ${ }^{113} \mathrm{He}$ muses:

How can classism be combated? Not very well, by a judge. Faced with the impossible problems of juvenile offenders for whom no facilities are available, we can do little more than beat our judicial breasts and try at least to make the community realize what we are doing. This may serve some purpose. One of the causes of class prejudice is the success with which the rich can ignore the poor. ... Perhaps judicial opinions, with the media coverage they sometimes receive, can do something to make

11 Bazelon, Racism, Classism, and the Juvenile Process, 53 Judicature 373, 374 (1970). 112 Judges cannot, by their own fiat, alter the environment that breeds juvenile offenders, nor can they take even the less drastic step of hiring counselors or constructing treatment facilities. Accordingly, if they see that young offenders are not being helped, are not receiving the care and rehabilitation promised them by the ideals of the juvenile system, their only alternative is to say, "If you insist upon treating him as a criminal, at least give the young offender the protections an adult offender receives." In short, don't give him "the worst of both worlds." Id. 375-76.

${ }^{113}$ Id. 377-78. 
the prosperous public and legislators realize what is happening and why in our cities. ${ }^{114}$

\section{F. Summary}

In this final quotation we again see how Judge Bazelon views the judiciary as community educators, and how he constantly works to bring critical issues before the public. He has devoted great personal effort to this task, and his writings demonstrate the breadth of his concerns. ${ }^{115}$ His efforts have been rewarded by appointment to teaching positions on an ever-increasing number of both medical and law faculties. He has gained world-wide acclaim as a leader in the effort to make intelligent use of our growing knowledge of the behavioral sciences in the context of law and social policymaking. These honors and that acclaim are richly deserved.

114 Id. 378.

115 For his thoughts on other pressing social concerns, see Bazelon, Alcoholism: An Ounce of Prevention, 52 Judicature 408 (1969); Bazelon, Mental Retardation: Some Legal and Moral Considerations, 35 AM. J. ORTHOpsychiat. 838 (1965). 